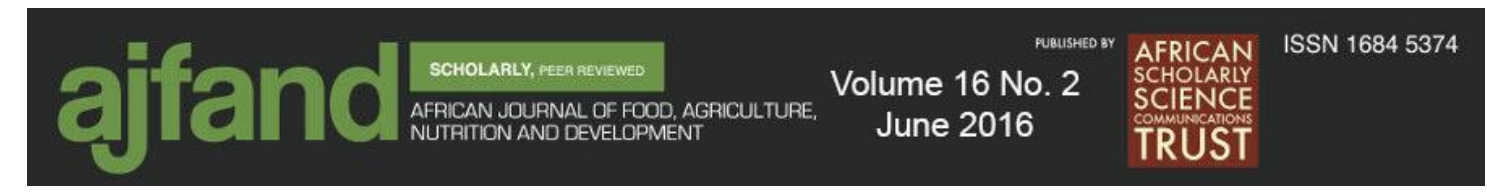

DOI: $10.18697 /$ ajfand.74.15105

\title{
MICROBIOLOGICAL ANALYSIS OF TRADITIONALLY FERMENTED MILK SOLD IN KINIGI SECTOR OF MUSANZE DISTRICT IN RWANDA
}

\section{Nzabuheraheza FD $^{1 *}$ and AN Nyiramugwera ${ }^{2}$}
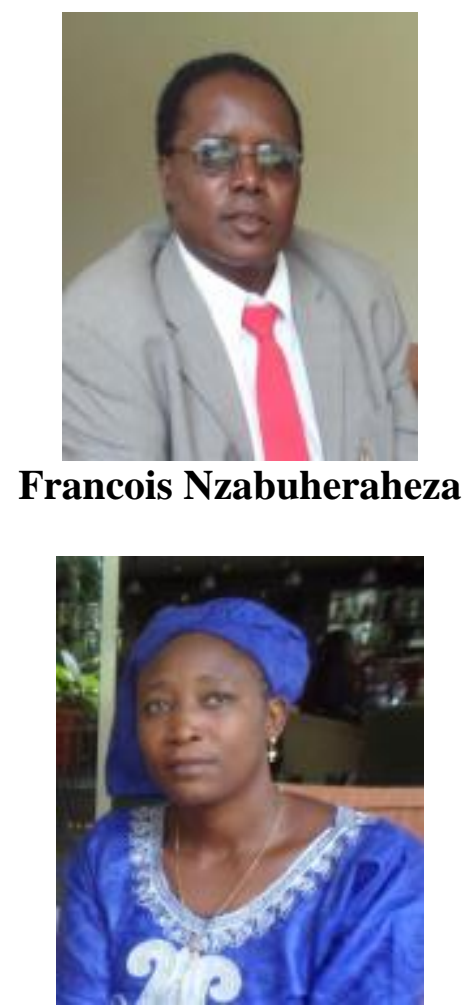

AN Nyiramugwera

*Corresponding Author: nzabufd@yahoo.fr / nzabufd1@gmail.com

${ }^{1}$ Department of Biotechnologies, Higher Institute of Education (Institut d'Enseignement Supérieur de Ruhengeri: INES-Ruhengeri), P.O. Box: 155 Ruhengeri, Musanze District, Rwanda

${ }^{2} \mathrm{PhD}$ Candidate in Small Scale Business at the Open University of Tanzania, Kibungo Campus located in Rwanda 


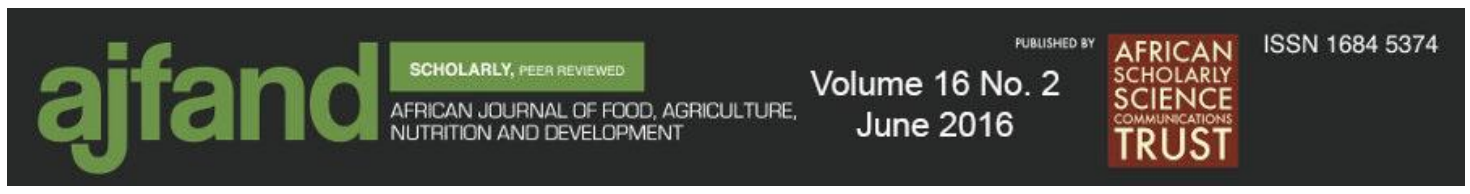

\section{ABSTRACT}

A research work entitled: "Microbiological analysis of traditionally fermented milk (Ikivuguto) sold in Kinigi Sector of Musanze District," was carried out at Higher Learning Institution of Applied Sciences (INES-Ruhengeri) Laboratory of Microbiology located near Volcanoes in the Northern Province of Rwanda. The main objective of this work was to determine the microbiological quality of traditionally fermented milk, which is consumed by Kinigi Center local people. The hypothesis was to analyze if traditionally fermented milk commercialized in Kinigi restaurants contained pathogenic bacteria such as fecal coliforms and Escherichia coli, in addition to staphylococci and yeasts. Milk samples were collected from Kinigi sector and examined in the microbiology laboratory in order to assess the microbiological quality and safety of traditionally fermented milk in rural areas. The samples were analyzed qualitatively and quantitatively for the microbes found in fermented milk sold in Kinigi Center, and the results were as follows: $7.21 \times 10^{7} \mathrm{CFU} / \mathrm{ml}$ for total counts; $3.89 \times 10^{7} \mathrm{CFU} / \mathrm{ml}$ for Lactobacillus; $2.77 \times 10^{7} \mathrm{CFU} / \mathrm{ml}$ for yeasts; $1.196 \times 10^{5} \mathrm{CFU} / \mathrm{ml}$ for total coliforms; $9.63 \times 10^{4} \mathrm{CFU} / \mathrm{ml}$ for fecal coliforms and $8.92 \times 10^{3} \mathrm{CFU} / \mathrm{ml}$ for staphylococci. Biochemical tests were carried out and the results showed that identified pathogens were E. coli, Providencia alcalifaciens, and the staphylococci group. It was found that fermented milk contained genera and species of Staphylococcus haemolyticus, Staphylococcus aureus, Staphylococcus intermedius, Staphylococcus xylosus and Staphylococcus saprophyticus. Findings showed that the commercial milk samples were cross-contaminated by different pathogens from environment. These contaminations could have been due to improper handling, presence of flies, soil erosion, dust from atmosphere, as well as contaminated milk vessels or pots, stirrers and unpasteurized water. It was concluded that local farmers and milk retailers did not adhere to required hygienic conditions for milk safety. In this regard, the sold traditional fermented milk does not meet health and safety standards because people did not respect good manufacturing practices. The hypothesis and main objective were confirmed, because traditionally fermented milk of Kinigi was cross-contaminated before consumption. Thus, it would be better to train farmers in the areas of product hygiene, sanitation and safety during milking, processing and marketing.

Key words: Cross-contamination, Escherichia coli traditionally fermented milk, Listeria monocytogenes, Staphylococcus aureus, Salmonella spp., Candida spp., milk spoilage 


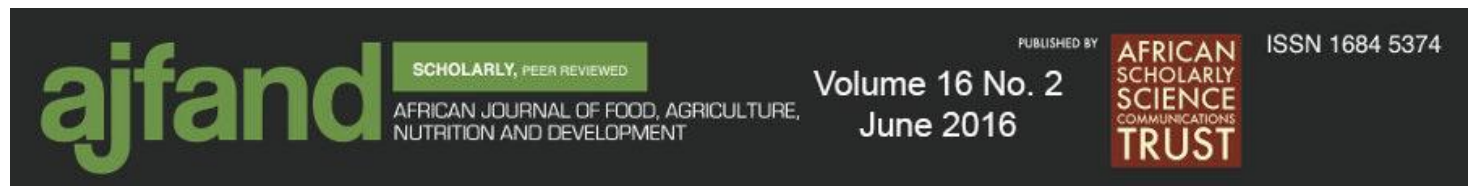

\section{INTRODUCTION}

Illnesses caused by consumption of contaminated milk products have a detrimental impact on the economy and public health worldwide [1]. So far, many pathogenic microorganisms, such as Escherichia coli, Listeria monocytogenes, Staphylococcus aureus, Salmonella spp., and Candida spp. have been reported as the causal agents of food-borne diseases and/or milk spoilage [2]. Milk and milk products are good media for microbial growth [3]. Microorganisms exist in farms where dairy cows are kept during milking [4]. The pasteurization of milk is necessary for killing pathogenic microorganisms before consumption [5, 6]. In Rwanda, traditionally fermented milk was used by ancestors from ancient times without pasteurization. Nowadays, the Rwanda Ministry of Agriculture is improving the quality of milk and milk products before delivering to consumers [7]. Milk and dairy products should meet the standards set by Rwanda Bureau of Standards (RBS) [8]. In general, the best milk quality remains an integral dietary component of meals sold in different supermarkets, restaurants, boutiques and hotels. Fermented milk is produced by farmers, business women and men and Rwandan dairy industries, such as Inyange, Nyabisindu, and Gishwati dairy plants among others. Milk is deemed to be an appropriate dietary item for the young and old people of the society [9]. Milk is considered to also be a good culture medium for microbial growth. In this regard, milk needs proper hygienic handling and safety in order to meet the standards [10]. Milk may contain pathogens, and indeed has historically been the vehicle of significant food borne-diseases, such as tuberculosis [11]. In rural areas, milk production is significantly increasing but the modern and appropriate techniques of milk hygiene; processing, preservation and packaging remain at embryonic state. Therefore, this research work investigated the level of pathogenic bacteria frequently found in traditionally fermented milk sold in the Kinigi region of Rwanda.

\section{PROBLEM STATEMENT}

In Kinigi Sector of Rwanda, farmers perform hand milking because modern facilities such as milking machines, stainless steel vessels and refrigeration cars are not available. Milk containers and tools are cleaned by using unpasteurized water, rain water, and polluted water from contaminated rivers. Therefore, milk contamination can occur during handling, fermentation, transportation and commercialization. There is yet no dairy plant in Rwanda that can meet milk product standards as set by RBS [8]. This implies that the dairy processing unit in Kinigi region is basically limited to traditional methods of fermentation, which leads to poor hygienic quality of fermented milk products.

Because milk processing in Kinigi farms takes place under unsanitary conditions and poor production practices, the products could contain pathogenic microorganisms. In addition, milk collected from different farms could be contaminated with pathogenic microorganisms present inside the udder, the exterior surfaces of the animal, milk handling equipment and air within the milking environment. These types of contaminations may cause some food-borne diseases. 


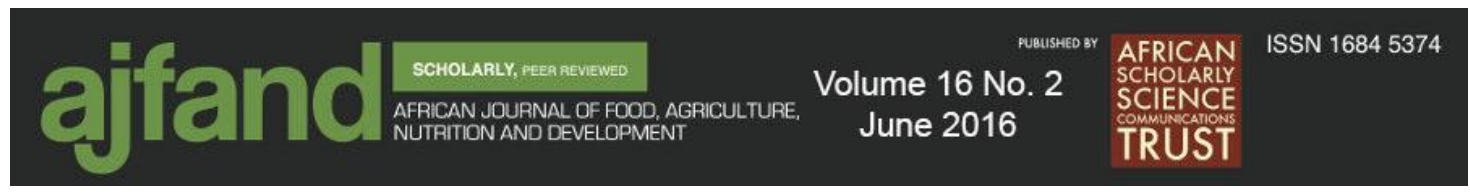

\section{MATERIALS AND METHODS}

\section{Fermented milk sampling}

The study was conducted in Kinigi region of Musanze District in Rwanda. In April 2013, four samples of traditionally fermented milk were collected randomly from plastic vessels of different local farmers called grocers. Samples were collected early in the morning in sterile glass bottles. Each sample $(200 \mathrm{ml})$ of traditionally fermented milk collected was refrigerated and transported to the laboratory for further microbiological analysis following RBS methods [8].

\section{Microbiological analysis of fermented milk}

Each sample was checked and then mixed with sterile peptone solution $(0.1 \%$; w/v). From these samples, serial decimal dilutions were prepared in $0.1 \%$ peptone solution. The microorganism counting was carried out by the pour-plate method with duplicate plating on different selective agar media according to standard methods $[5,8]$.

Total aerobic mesophilic bacteria were enumerated on Plate Count Agar after incubation in aerobic conditions at $30 \pm 1^{\circ} \mathrm{C}$ for $48 \mathrm{~h}$, while coliform counts were determined by the Violet Red Bile Agar with plate incubation at $35 \pm 2{ }^{\circ} \mathrm{C}$ for $48 \mathrm{~h}$ according to standard methods $[5,8]$.

The presumptive step was conducted with Lauryl Sulfate Tryptose broth $\left(35^{\circ} \mathrm{C}\right.$ for $48 \mathrm{~h}$ ) followed by the confirmation of total coliforms using Brilliant Green Bile broth $\left(35^{\circ} \mathrm{C}\right.$ for $48 \mathrm{~h})$. Thermotolerant coliforms were confirmed using Escherichia coli broth $\left(44.5^{\circ} \mathrm{C}\right.$ for $48 \mathrm{~h})$ and tryptone broth $\left(35^{\circ} \mathrm{C}\right.$ for $\left.48 \mathrm{~h}\right)$ followed by indole production detection [5].

Fungi were enumerated on Potato Dextrose Agar following the pour-plate method and incubated at $25^{\circ} \mathrm{C}$ for $5-7$ days according to RBS [8]. The detection of Salmonella spp. and Staphylococcus aureus, was performed according to standard methods [5, 8]. Staphylococcus aureus as Gram-positive cocci were identified by the test of catalase positivity, coagulase and mannitol positivity. Normally, the routine identification and enumeration of foodborne pathogens including $S$. aureus and E. coli in fermented milk were carried out by conventional methods based on the use of selective media such as Baird-Parker and MacConkey agar, respectively following identification of suspicious colonies by biochemical reactions and DNASE test $[5,8]$.

\section{Statistical analysis}

Data were statistically analyzed using the Excel software.

\section{RESULTS}

Table 1 shows the enumeration of microorganisms present in the traditional fermented milk (called "Ikivuguto" in Rwandan language) per $1 \mathrm{ml}$ of sample (expressed in $\mathrm{CFU} / \mathrm{ml}$ ) and the average of five samples taken at different retailers of Kinigi Center or selling shops. 


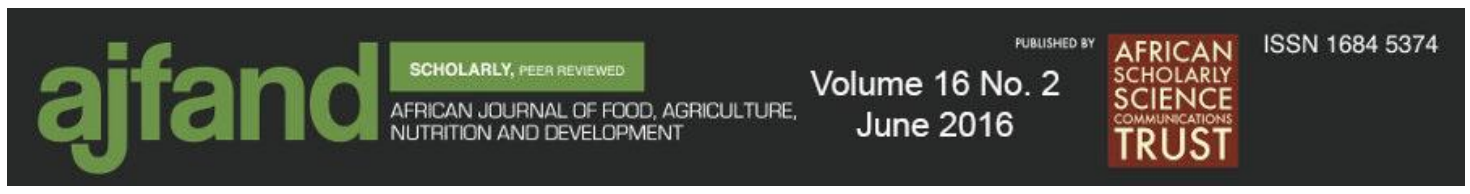

It was found that the average total counts had about $7.21 \times 10^{7} \mathrm{CFU} / \mathrm{ml}$ of examined fermented milk. The level of staphylococci was about $8.92 \times 10^{3} \mathrm{CFU} / \mathrm{ml}$ in traditional milk fermented without pasteurization in rural areas. Table 2 shows the different Gram stain and microscopic examination carried out for the isolation and determination of Staphylococcus aureus. The results obtained showed Gram positive, cocci in shape and catalase positive. Catalase test was used to differentiate streptococci and from staphylococci. Table 3 shows the results of Staphylococcus system and suggested nomenclature of different strains taken on each sample. Out of 5 strains tested by using Staph-system 18R, one strain was identified as S. haemolyticus, one strain as $S$. aureus, one strain as $S$. intermedius, one strain as $S$. xylosus, and one strain as $S$. saprophyticus.

Table 4 illustrates gram stain, shape and other biochemical tests of 15 strains isolated from 5 samples of Ikivuguto on the violet red bile lactose agar as a culture medium for coliforms bacteria isolation.

Table 4 shows that Gram stain is negative and the strains number 13 and 14 of Kampanga sample; 7, 8,9,10,11, 12 of Rukore and Cyanturo; 1 and 4 of Bisate and Rushubi reacted negatively on citrate utilization. The results mean that they are E. coli while other strains that reacted positive are $P$. alcalifaciens according to the previous tests. Therefore, according to the identified strains, E. coli was present at $66.7 \%$ and $P$. alcalifaciens at $33.3 \%$.

\section{DISCUSSION}

The results obtained during the laboratory analysis of traditionally fermented milk were classified according to their groups and the discussion was done on the total bacteria counts, staphylococci bacteria as well as total and fecal coliforms, lactic acid bacteria, yeasts and molds.

After microbiological analysis, it was found that $7.21 \times 10^{7} \mathrm{CFU} / \mathrm{ml}$ were counted in traditionally fermented milk. This number is higher than that obtained by Ryoba [9] and Tamime [10] who found total bacterial counts of $13.29 \times 10^{6} \mathrm{CFU} / \mathrm{ml}$ and $4.37 \times 10^{6}$ $\mathrm{CFU} / \mathrm{ml}$, respectively. The French Standard for fermented milk recommends that the total bacteria count should not exceed $5 \times 10^{4} \mathrm{CFU} / \mathrm{ml}$. The legal limit for bacteria in fermented milk is $1.0 \times 10^{5} \mathrm{CFU} / \mathrm{ml}[8]$.

This result remains higher according to the suggested standard [8]. This means that contaminating bacteria entered the milk from a variety of possible sources.

During the experiment, the enumeration of staphylococci gave $8.92 \times 10^{3} \mathrm{CFU} / \mathrm{ml}$ for Ikivuguto, which is within the range of the results found by another researcher [9], who reported that the staphylococcal levels are usually lower initially ( $<100 \mathrm{CFU} / \mathrm{g}$ or per $\mathrm{ml})$. However, the organisms can grow to levels higher than $10^{6} \mathrm{CFU} / \mathrm{ml}$ (or per $\mathrm{g}$ ) and cause staphylococcal food poisoning under favorable conditions. According to the identification of staphylococci, 6 strains identified during laboratory analysis such as $S$. haemolyticus, S. aureus, S. intermedius, S. xylosus and S. saprophyticus, S. epidermidis 


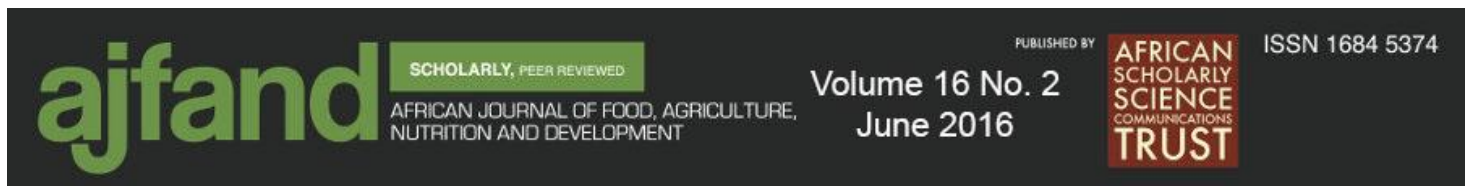

and are responsible for mastitis [10]. The RBS norm for pathogenic microorganisms is equal to nil per $\mathrm{ml}$, which is lower than the $8.92 \times 10^{3} \mathrm{CFU} / \mathrm{ml}$ found in this study [8].

The presence of these bacteria groups in fermented milk samples indicates consumed milk contamination.

From current work, the average total coliforms was $1.196 \times 10^{5} \mathrm{CFU} / \mathrm{ml}$ of fermented milk while fecal coliforms was $9.63 \times 10^{4} \mathrm{CFU} / \mathrm{ml}$. This high total and fecal coliform concentration may have been as a result of poor handling conditions during fermentation and manipulation. However, Ryoba [9] reported a value of $3.5 \times 10^{4} \mathrm{CFU} / \mathrm{ml}$ in traditionally fermented milk, which is less than results obtained in this work.

The results of Lactobacillus were $3.89 \times 10^{7} \mathrm{CFU} / \mathrm{ml}$ and $7.40 \pm 0.19$ of $\log \mathrm{CFU} / \mathrm{ml}$, which are less than the result obtained for fermented milk with about $1.1 \pm 0.4 \times 10^{8} \mathrm{CFU} / \mathrm{ml}$. The results are similar to those obtained by another researcher [9] who reported $4.16 \times 10^{7}$ Lactobacillus colonies for fermented milk.

Yeasts and molds constitute the major indicator of general essential quality. These microorganisms come from the environment, and contaminated crop products [10].

The results of enumeration of yeasts indicated about $2.77 \times 10^{7} \mathrm{CFU} / \mathrm{ml}$, while the findings obtained by other researchers [4] showed that traditionally fermented milk had about $0.7 \times 10^{8} \mathrm{CFU} / \mathrm{ml}$ of yeasts. It was found that the examined milk had a higher contamination and could not meet RBS standards [8], where the maximum number of yeasts and molds in fermented milk is about $20 \mathrm{CFU} / \mathrm{ml}$.

\section{CONCLUSION}

The contamination of fresh raw milk and consequently fermented milk using traditional methods in the Kinigi region depends greatly on hygiene and sanitation conditions during milking, handling, fermentation and commercialization. The sources of cross contamination could be unwashed udder and teat (mammillae), poor sanitation of milking area (pen or stable as farm building for housing dairy cows), equipments and tools.

Pathogenic bacteria such as coliforms and streptococci, staphylococci and yeasts were the most abundant in fermented milk of Kinigi Sector of Musanze District. Heat treatment of raw milk and proper handling during or after milk fermentation seem to be neglected by farmers and retailers or sellers. The average of total counts, staphylococci, lactobacilli, total and fecal coliforms, yeasts and molds of 5 samples were $7.21 \times 10^{7}$ $\mathrm{CFU} / \mathrm{ml}, 8.92 \times 10^{3} \mathrm{CFU} / \mathrm{ml}, 3.89 \times 10^{7} \mathrm{CFU} / \mathrm{ml}, 1.196 \times 10^{5} \mathrm{CFU} / \mathrm{ml}, 9.63 \times 10^{4} \mathrm{CFU} / \mathrm{ml}$ and $2.77 \times 10^{7} \mathrm{CFU} / \mathrm{ml}$, respectively. Different pathogens were identified in order to determine the safety of traditionally fermented milk sold in rural area of Kinigi. Thus, the hypotheses were verified and the objectives were achieved, because obtained results showed that the examined traditional fermented milk quality is not safe for consumption and does not meet the standards set by RBS [8]. 


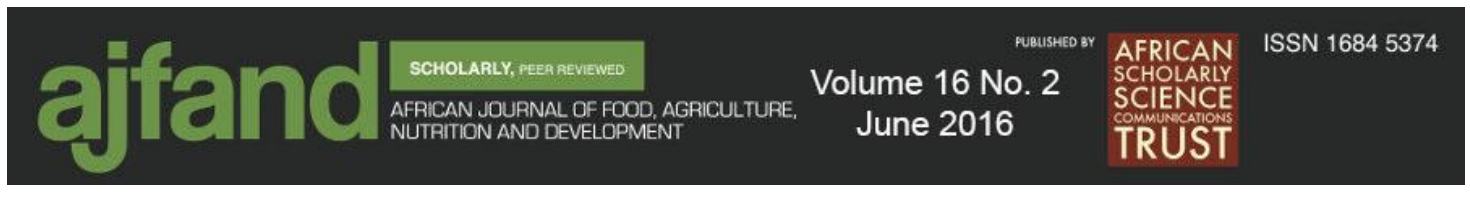

\section{RECOMMENDATIONS}

During hand-milking, it would be better to wash hands, udder and teats with soap, potable warm water and then wipe with clean cloth or towel, and milk equipment. Farmers should observe proper hygiene, milking area sanitation and milk pasteurization by cooking method. During milk fermentation, pure starter culture should be used. Normally, milk equipment and tools should be made of stainless steel. Milk safety and quality should meet the standards set by RBS [8].

\section{ACKNOWLEDGEMENTS}

Many thanks go to INES-Ruhengeri Administration for technical assistance, and supervised student, Mr. Jean Félix Muhire, a biotechnologist for his willing collaboration under the auspices of the Department of Biotechnologies at INES-Ruhengeri. 


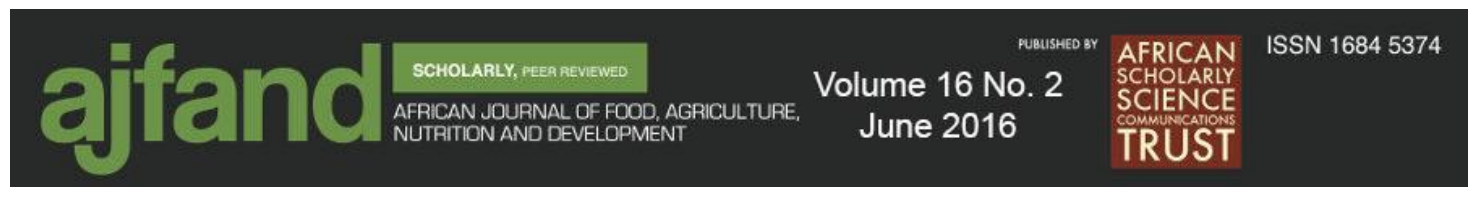

Table 1: Microorganisms (CFU per $\mathrm{ml}$ ) found in traditional fermented milk "Ikivuguto"

\begin{tabular}{|c|c|c|c|c|c|c|}
\hline \multirow{3}{*}{ 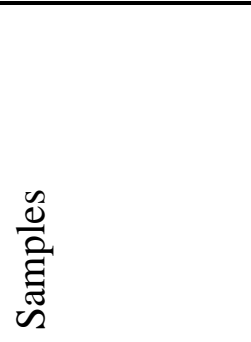 } & \multicolumn{6}{|c|}{ Identified Microorganisms expressed in CFU/ml } \\
\hline & $\begin{array}{l}\text { Total } \\
\text { counts }\end{array}$ & Staphylococci & Lactobacilli & $\begin{array}{l}\text { Total } \\
\text { coliforms }\end{array}$ & $\begin{array}{l}\text { Fecal } \\
\text { coliforms }\end{array}$ & $\begin{array}{l}\text { Yeasts and } \\
\text { molds }\end{array}$ \\
\hline & PCA & $\mathrm{BP}$ & MRS & VRBL & VRBL & PDA \\
\hline BISATE & $2.98 \times 10^{7}$ & $3.1 \times 10^{2}$ & $1.19 \times 10^{7}$ & $8.46 \times 10^{3}$ & $5.46 \times 10^{3}$ & $9.51 \times 10^{6}$ \\
\hline RUSHUBI & $7 \mathrm{X} 10^{7}$ & $3.88 \times 10^{3}$ & $1.71 \times 10^{7}$ & $3.64 \times 10^{4}$ & $\begin{array}{l}0 \quad(\text { not } \\
\text { present })\end{array}$ & $6.8 \times 10^{7}$ \\
\hline RUKORE & $1.19 \times 10^{7}$ & $4.2 \times 10^{2}$ & $8.17 \times 10^{6}$ & $2.45 \times 10^{3}$ & $\begin{array}{l}0 \quad(\text { not } \\
\text { present })\end{array}$ & $1.07 \times 10^{6}$ \\
\hline CYANTURO & $1.58 \times 10^{8}$ & $2.59 \times 10^{4}$ & $8.53 \times 10^{7}$ & $5.51 \times 10^{5}$ & $4.76 \times 10^{5}$ & $4.48 \times 10^{7}$ \\
\hline KAMPANGA & $9.06 \times 10^{7}$ & $1.41 \times 10^{4}$ & $7.2 \times 10^{7}$ & $\begin{array}{l}0 \quad(\text { not } \\
\text { present })\end{array}$ & $\begin{array}{l}0 \quad(\text { not } \\
\text { present })\end{array}$ & $1.51 \times 10^{7}$ \\
\hline $\begin{array}{l}\text { Average of } \\
\text { CFU/ml }\end{array}$ & $7.21 \times 10^{7}$ & $8.92 \times 10^{3}$ & $3.89 \times 10^{7}$ & $1.196 \times 10^{5}$ & $9.63 \times 10^{4}$ & $2.77 \times 10^{7}$ \\
\hline
\end{tabular}

CFU/ml: Colony Forming Units per ml 


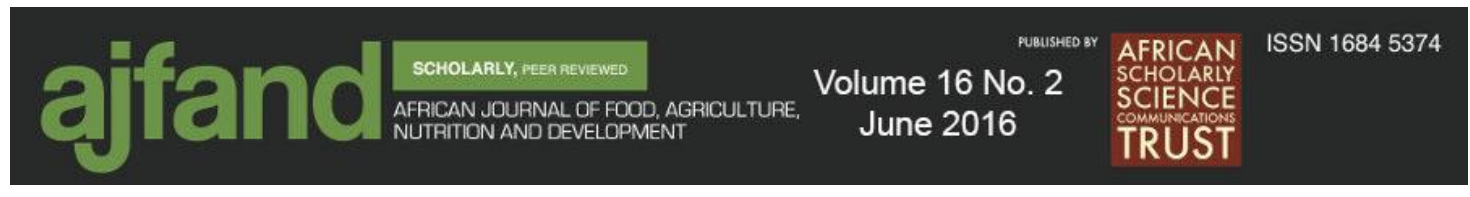

Table 2: Identification of Staphylococci in fermented milk sample

\begin{tabular}{|c|c|c|c|c|c|}
\hline $\begin{array}{l}\text { Lab. tests } \\
\text { No of } \\
\text { Samples }\end{array}$ & $\begin{array}{ll}\text { No of } \\
\text { isolated } \\
\text { strains }\end{array}$ & Gram stain & Shape & Catalase test & DNASE test \\
\hline \multirow{4}{*}{ BISATE } & 1 & + & Cocci & + & - \\
\hline & 2 & + & Cocci & + & - \\
\hline & 3 & + & Cocci & + & + \\
\hline & 4 & + & Cocci & + & - \\
\hline \multirow[b]{2}{*}{ RUSHUBI } & 5 & + & Cocci & + & + \\
\hline & 6 & + & Cocci & + & + \\
\hline \multirow[b]{2}{*}{ RUKORE } & 7 & + & Cocci & + & - \\
\hline & 8 & + & Cocci & + & - \\
\hline \multirow[b]{2}{*}{ CYANTURO } & 9 & + & Cocci & + & - \\
\hline & 10 & + & Cocci & + & - \\
\hline \multirow[b]{2}{*}{ KAMPANGA } & 11 & + & Cocci & + & - \\
\hline & 12 & + & Cocci & + & - \\
\hline
\end{tabular}




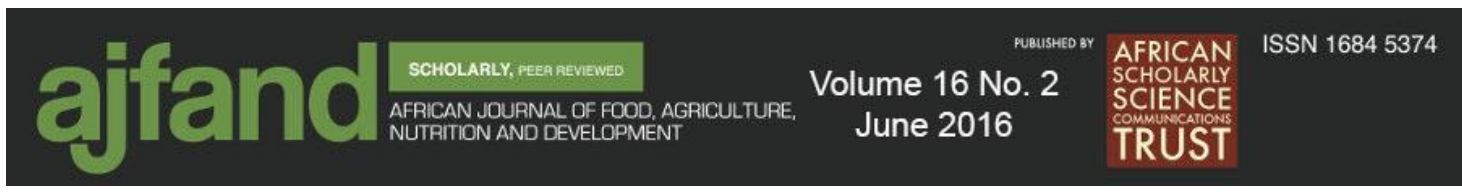

Table 3: Characterization of Staphylococci strains and suggested nomenclature

\begin{tabular}{|c|c|c|c|c|c|}
\hline $\begin{array}{l}\text { Strains } \\
\text { Lab. Tests }\end{array}$ & 1 & 2 & 3 & 4 & 5 \\
\hline$\overline{A R G}$ & + & $\mathrm{V}$ & $\mathrm{V}$ & - & - \\
\hline$\overline{\mathrm{UR}}$ & - & + & + & + & $\mathrm{V}$ \\
\hline VP & $\mathrm{V}$ & + & - & $\mathrm{V}$ & + \\
\hline NIT & $\mathrm{V}$ & + & + & $\mathrm{V}$ & - \\
\hline$\overline{\mathrm{ONPG}}$ & - & $\mathrm{V}$ & + & + & $\mathrm{V}$ \\
\hline NOV & - & - & - & + & $\mathrm{V}$ \\
\hline MAL & + & + & $\mathrm{V}$ & + & + \\
\hline$\overline{T R E}$ & + & + & + & + & + \\
\hline MAN & $\mathrm{V}$ & + & $\mathrm{V}$ & $\mathrm{V}$ & $\mathrm{V}$ \\
\hline$\overline{X Y L}$ & - & - & - & + & - \\
\hline$\overline{\mathrm{XYT}}$ & - & - & - & $\bar{V}$ & $\mathrm{~V}$ \\
\hline CEL & - & - & - & - & - \\
\hline$\overline{S A C}$ & + & + & + & + & + \\
\hline$\overline{\text { MMN }}$ & - & + & + & + & - \\
\hline RIB & $\mathrm{V}$ & + & + & $\mathrm{V}$ & - \\
\hline RAF & - & - & - & - & - \\
\hline$\overline{\mathrm{LAC}}$ & $\overline{\mathrm{V}}$ & $\mathrm{V}$ & $\mathrm{V}$ & $\overline{\mathrm{V}}$ & $\mathrm{V}$ \\
\hline FRU & $\mathrm{V}$ & + & + & + & + \\
\hline $\begin{array}{l}\text { Suggested } \\
\text { nomenclature }\end{array}$ & S. haemoliticus & S. aureus & S. intermedius & S. xylosus & $\begin{array}{l}S . \\
\text { saprophy } \\
\text { ticus }\end{array}$ \\
\hline
\end{tabular}




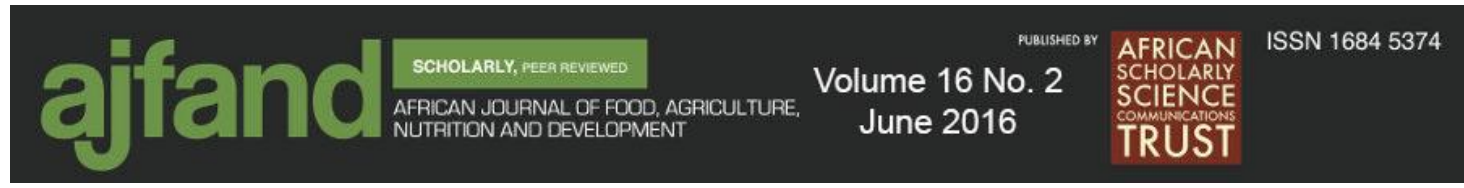

Table 4: Characterization and suggested nomenclature of coliforms bacteria

\begin{tabular}{|c|c|c|c|c|c|c|c|c|c|c|c|c|}
\hline No of samples & $\stackrel{\mathscr{E}}{\stackrel{\tilde{\pi}}{\leftrightarrows}}$ & 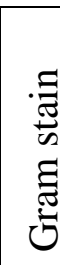 & 胥 & 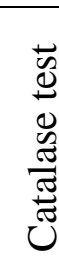 & 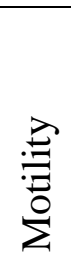 & $\frac{\frac{0}{0}}{\frac{O}{G}}$ & 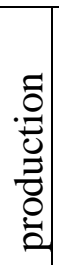 & $\mathbb{J}$ & 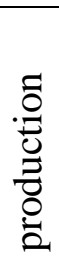 & $\stackrel{\stackrel{\mathscr{*}}{\leftrightarrows}}{:}$ & : & $\begin{array}{l}\text { Suggested } \\
\text { Nomenclature }\end{array}$ \\
\hline \multirow{3}{*}{ BISATE } & 1 & - & Rod & + & + & + & & + & & - & & E. coli \\
\hline & 2 & - & Rod & + & + & + & & + & & + & & $\begin{array}{l}P . \\
\text { alcalifaciens }\end{array}$ \\
\hline & 3 & - & Rod & + & + & + & & + & & + & & $\begin{array}{l}P . \\
\text { alcalifaciens }\end{array}$ \\
\hline \multirow{3}{*}{ RUSHUBI } & 4 & - & Rod & + & + & + & & + & & - & & E. coli \\
\hline & 5 & - & Rod & + & + & + & & + & & + & & $\begin{array}{l}P . \\
\text { alcalifaciens }\end{array}$ \\
\hline & 6 & - & Rod & + & + & + & & + & & + & & $\begin{array}{l}P . \\
\text { alcalifaciens }\end{array}$ \\
\hline \multirow{3}{*}{ RUKORE } & 7 & - & Rod & + & + & + & & + & & - & & E. coli \\
\hline & 8 & - & Rod & + & + & + & & + & & - & & E. coli \\
\hline & 9 & - & Rod & + & + & + & & + & & - & & E. coli \\
\hline \multirow{3}{*}{ CYANTURO } & 10 & - & Rod & + & + & + & & + & & - & & E. coli \\
\hline & 11 & - & Rod & + & + & + & & + & & - & & E. coli \\
\hline & 12 & - & Rod & + & + & + & & + & & - & & E. coli \\
\hline \multirow{3}{*}{ KAMPANGA } & 13 & - & Rod & + & + & + & & + & & - & & E. coli \\
\hline & 14 & - & Rod & + & + & + & & + & & - & & E. coli \\
\hline & 15 & - & Rod & + & + & + & & + & & + & & $\begin{array}{l}P . \\
\text { alcalifaciens }\end{array}$ \\
\hline
\end{tabular}

E: Escherichia; P: Providencia 


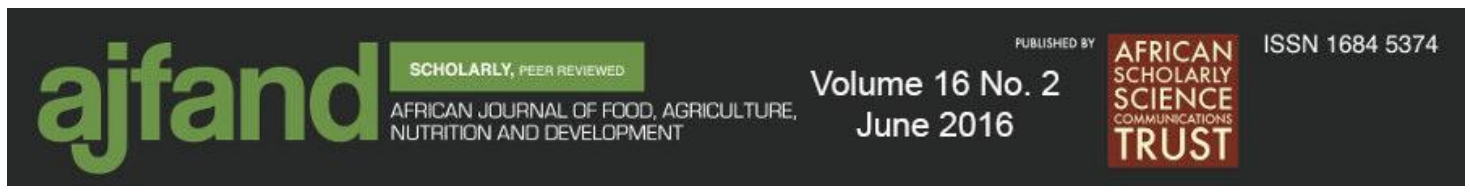

\section{REFERENCES}

1. Atkins S Milk under the microscope. Vermont Extension service, University of Vermont, 1992; 25-42.

2. Burton $\mathbf{H}$ and SP Thieulin Milk Sterilization, Food and Agriculture Organization of the United Nations (FAO), Italy, $2^{\text {nd }}$ edition, 1969; 2-51.

3. Eckles CH, Combs WB and $\mathbf{H}$ Macy Milk and Milk Products, $4^{\text {th }}$ Edition USA. Reprinted by McGraw-Hill Publishing Company Limited, New Delhi, India, $1973 ; 102-131$.

4. Hafez ESE Reproduction in Farm Animals. Printed in USA, $3^{\text {rd }}$ edition, 1975; 216.

5. Benson HJ Microbiological applications, Laboratory manual in general microbiology, eighth edition, McGraw-Hill, Paseta city college, USA, 2002; 55452.

6. Harold M Milk and milk products, $4^{\text {th }}$ edition, New York, 1998; 10-21.

7. Minagri (Ministry of Agriculture) Strategic plan (2000-2010), Kigali-Rwanda, 2007; 35-55.

8. $\quad$ RBS Standards for fermented milk, Kigali, Rwanda, RS 43-2004; 48-75.

9. Ryoba $\mathbf{R}$ Milk handling quality control and processing into dairy products, Sokoine University of Agriculture, 2004; 400-488. Tanzania J. Agric. Sc. (2004).

10. Tamime AY The microflora of bulk collect milk part 1. Dairy Ind. Int., India, 2009; 9-37.

11. Walstra P, Wouters JM and TJ Geurts Dairy Sciences and Technology, Wageningen, The Netherlands, 2005; 23-156. 